\title{
SUTURING A WOUNDED BODY - WOUNDED MIND IN RED SILK ON WHITE LINEN: EMBODIED AND HAND(Y) KNOWLEDGE OF TRAUMA
}

\author{
MAUREEN DALY GOGGIN ${ }^{1}$ \\ Arizona State University, U.S.A.
}

\begin{abstract}
In 1830, Elizabeth Parker, daughter of a day laborer and of a teacher in Ashburnham, East Sussex, England, cross-stitched in red silk thread an extraordinarily complex text that participates in several genres, including a memoir of her then brief life of some seventeen years, a confession, a suicide note, and a prayer. These various genres cohere around one momentous event in Parker's young life: the sexual violation and physical abuse at the hands of her employer, Lt. G. After suturing 46 lines, 1,722 words, and 6,699 characters, she stops mid-line and mid-way down her cloth with the powerful plea, "What will become of my soul[?]" This paper argues that Parker's sampler was a robust site in which Parker was able to grapple with her wounded body and mind. To justify the claim that a woman's stitching can be interpreted as an epistemic activity, the proposed paper turns to two key concepts "situated knowledges" and "embodied knowledge"both of which have been posited by feminists as a way to destabilize the dominant validation of disembodied, abstract thinking where the eye serves as the mind's tool of investigation. (Haraway; Knappett; Frank; Driver)
\end{abstract}

\footnotetext{
${ }^{1}$ I want to acknowledge the generous assistance of the following textiles historians and keepers who kindly answered numerous questions, shared materials with me, and gave me access to rare samplers: Clare Browne, Curator of Textiles and Dress, Victoria and Albert Museum, London; Edwina Ehrman, Curator of Costume and Decorative Art, Museum of London; Carol Humphrey, Honorary Keeper, Textiles, Fitzwilliam Museum, Cambridge, England; and Joy Jarrett and Rebecca Scott of Witney Antiques, Oxfordshire, England. I also want to acknowledge the following people for their invaluable help: Chris Marsden and the staff at the Victoria and Albert Museum Archives; Jennifer Nash and the staff at the East Sussex Records Office in Lewes; the staff at the West Sussex Record Office in Chichester; the staff at the Family Records Centre in London; and the staff at the Public Records Office in Kew. A version of this essay appears in Women and the Material Culture of Needlework and Textiles, 17501950, edited by Maureen Daly Goggin and Beth Fowkes Tobin. Farnham, Surrey, England: Ashgate, 2009. 17-42.
} 
Keywords: feminism, rhetoric, material culture

I've been a hard worker all my life, but most all my work has been the kind that 'perishes with usin',' as the Bible says. That's the discouragin' thing about a woman's work. . . . I've always had the name of bein' a good housekeeper, but when I'm dead and gone there ain't anybody goin' to think o' the floors I've swept, and the tables I've scrubbed, and the old clothes I've patched, and the stockin's I've darned. . . . But when one of my grandchildren or greatgrandchildren sees one o' these quilts, they'll think about Aunt Jane, and, wherever I am then, I'll know I ain't forgotten. (Hall 97)

Eliza Calvert Hall's Aunt Jane of Kentucky claimed quilting as a rhetorical space where she could leave her mark. Given the ephemeral nature of so much of "women's work" and the limited access nineteenth-century women had to rhetorical spaces, Aunt Jane's claim to material strategies for making her mark calls attention to the importance of examining material objects as epistemic spaces. As Carol Mattingly observes of nineteenth-century women rhetors, "since many of the traditional tools of rhetoric were denied them, women found it necessary to consider techniques beyond masculine speakers' attention to argument and delivery." (Appropriate[ing] Dress 4) ${ }^{1}$ Needlework offered women, like Aunt Jane, one such rhetorical technique ${ }^{2}$.

${ }^{1}$ Of course, this is not to say that nineteenth-century women did not participate in public spaces or in agonistic rhetoric. Indeed, as the following scholars clearly show, despite the historical commonplace that women were barred from public spaces, a goodly number of nineteenth century women successfully, though not without resistance, moved into the public fora: June Hadden Hobbs. "I Sing for I Cannot Be Silent": The Feminization of American Hymnody, 1870-1920. Pittsburgh: University of Pittsburgh Press, 1997; Carol Mattingly. Well-Tempered Women: Nineteenth-Century Temperance Rhetoric. Carbondale: Southern Illinois University Press, 1998; Shirley W. Logan. We Are Coming: The Persuasive Discourse of Nineteenth-Century Black Women. Carbondale: Southern Illinois University Press, 1999; Carla L. Peterson. Doers of the Word: AfricanAmerican Women Speakers and Writers in the North (1830-1880). New York: Oxford University Press, 1995; and Jacqueline Jones Royster. Traces of a Stream: Literacy and Social Change Among African-American Women. Pittsburgh: University of Pittsburgh Press, 2000. Thus, we need to treat historical commonplaces, especially those concerning marginalized individuals and groups, with some skepticism. See also, Richard Leo Enos. "The Archaeology of Women in Rhetoric: Rhetorical Sequencing as a Research Method for Historical Scholarship.” Rhetoric Society Quarterly 32 (2002): 65-80; and Carol Mattingly. "Telling Evidence: Rethinking What Counts in Rhetoric." Rhetoric Society Quarterly 32 (2002): 99-108.

${ }^{2}$ See Rozsika Parker. The Subversive Stitch: Embroidery and the Making of the Feminine. 1984; reprint, New York: Routledge, 1989, for an important discussion of the significant and varied uses for which women have plied their needles. 
Focusing scholarly attention on material culture as a site for alternative rhetorical techniques calls attention to at least three questions: How do those who are denied access, typically by virtue of their gender, race, ethnicity, class and sexual orientation, to dominant, ma(i)n/stream discursive spaces construct and engage in rhetoric? How do we as scholars devise methods for theorizing and historicizing rhetorical practices that take place in the shadows or on the margins of these spaces? To what degree can material practices and artifacts be understood as rhetorical?

Over the last ten years, feminist historians of rhetoric and material culture have begun to tackle complex questions along these lines as they have tilled important new scholarly ground in their efforts to recoup neglected women rhetors and previously overlooked feminist traditions. ${ }^{1}$ In terms of rhetoric scholarship, as Patricia Bizzell points out, over the last decade "few, if any, other areas of research in the history of rhetoric have produced such rich results of this kind as feminist research." (Bizzell 7)

The feminist turn in rhetoric has made a significant contribution by drawing attention to the need for studying a broader range of rhetorical spaces,

${ }^{1}$ Karlyn Kohrs Campbell. Man Cannot Speak for Her: A Critical Study of Early Feminist Rhetoric, 2 vols. Westport, CT: Greenwood, 1989; Cheryl Glenn. Rhetoric Retold: Regendering the Tradition from Antiquity through the Renaissance. Carbondale: Southern Illinois University Press, 1997; June Hadden Hobbs. "I Sing for I Cannot be Silent." The Feminization of American Hymnody, 1870-1920. Pittsburgh: University of Pittsburgh Press, 1997.; Susan C. Jarratt. Rereading the Sophists: Classical Rhetoric Refigured. Carbondale: Southern Illinois University Press, 1991; Shirley W. Logan. We Are Coming: The Persuasive Discourse of Nineteenth-Century Black Women. Carbondale: Southern Illinois University Press, 1999; Andrea A. Lunsford, ed., Reclaiming Rhetorica Women in the Rhetorical Traditio. Pittsburgh: University of Pittsburgh Press, 1995; Carol Mattingly, Well-Tempered Women: : Nineteenth-Century Temperance Rhetoric. Carbondale: Southern Illinois University Press, 1998, and Appropriate[ing] Dress: Women's Rhetorical Style in Nineteenth-Century America. Carbondale: Southern Illinois University Press, 2002; Carla L. Peterson, Doers of the Word African-American Women Speakers and Writers in the North (1830-1880). New York: Oxford University Press, 1995; Krista Ratcliffe. Anglo-American Feminist Challenges to the Rhetorical Traditions: Virginia Woolf, Mary Daly, Adrienne Rich. Carbondale: Southern Illinois University Press, 1996; Jacqueline Jones Royster. Traces of a Stream: Literacy and Social Change among African-American Women. Pittsburgh: University of Pittsburgh Press, 2000; Christine Mason Sutherland, and Rebecca Sutcliffe, eds. The Changing Tradition: Women in the History of Rhetoric. Calgary: University of Calgary Press, 1999; Molly Meijer Wertheimer, ed. Listening to their Voices: Essays on the Rhetorical Activities of Historical Women. Columbia: University of South Carolina Press, 1997.

1 Patricia Bizzell. "Feminist Methods of Research in the History of Rhetoric: What Difference Do They Make?" Rhetoric Society Quarterly 30 (2000): 7. 
practices and artifacts than previously treated. Richard Leo Enos for example, argues:

If we are to provide a sensitive accounting of women in the rhetorical tradition, current methods of, and perspectives on, historical research need to be reconsidered and adjusted in three respects. First, our mentality toward rhetoric must expand beyond civic, agonistic discourse to include alternative modes of expression used by women. Second, our efforts to discover primary evidence must intensify so that a more representative body of sources becomes available. This expanded body of evidence must include non-traditional sources that provide insight into the oral and literate practices of women. Third, historians of rhetoric must create methods of research and analysis that will provide a more sensitive accounting of primary material than current historical methods were designed to yield. (65)

In a similar vein, Carol Mattingly in her essay "Telling Evidence: Rethinking What Counts in Rhetoric" challenges rhetoric historians to rethink what counts as rhetorical evidence (2002). Elsewhere she notes, "one component that contributes to our understanding and appreciation of women in the history of rhetoric is evidence crucial to the effectiveness but heretofore ignored because of its insignificance for men." (Appropriate[ing] Dress 4) Christine Mason Sutherland calls for more scholarship on rhetorical fora and practices other than civic and agonistic - that is, more work on sermo (the rhetoric of private and semi-public spaces) as a counterbalance to all that has been done on contentio (the rhetoric of the agora). (120) The feminist turn in material culture studies also offers a space for exploring meaning-making activities that extend our gaze beyond text-centric objects. In turning attention to the various kinds of artifacts women have made, used, and collected as well as the tools they have used to create objects, scholars in material culture have carved a space for rethinking what counts as epistemic evidence and who counts in our investigations. ${ }^{1}$

This essay may be understood as contributing to the feminist turn in the history of rhetoric and material culture. Here, I show how discoursing in "pen of steele and silken inke" both participates in, and offers an alternative to, a complex web of rhetorical spaces, practices, and artifacts. More specifically, I focus on one needlework sampler stitched in circa 1830 by Elizabeth Parker, a young lower-class English woman from Ashburnham, East Sussex, England, to demonstrate the ways in which stitching may be understood as powerful epistemic practice, and in Parker's case, served to stitch her life.

${ }^{1}$ See, for example, Marla R. Miller. The Needle's Eye: Women and Work in the Age of Revolution. Amherst: University of Massachusetts Press, 2006; Laurel Thatcher Ulrich. The Age of Homespun: Objects and Stories in the Creation of an American Myth. New York: Alfred A. Knof, 2001; Jennie Batchelor and Cora Kaplan. Women and Material Culture, 1660-1830. New York: Palgrave MacMillan, 2007. 


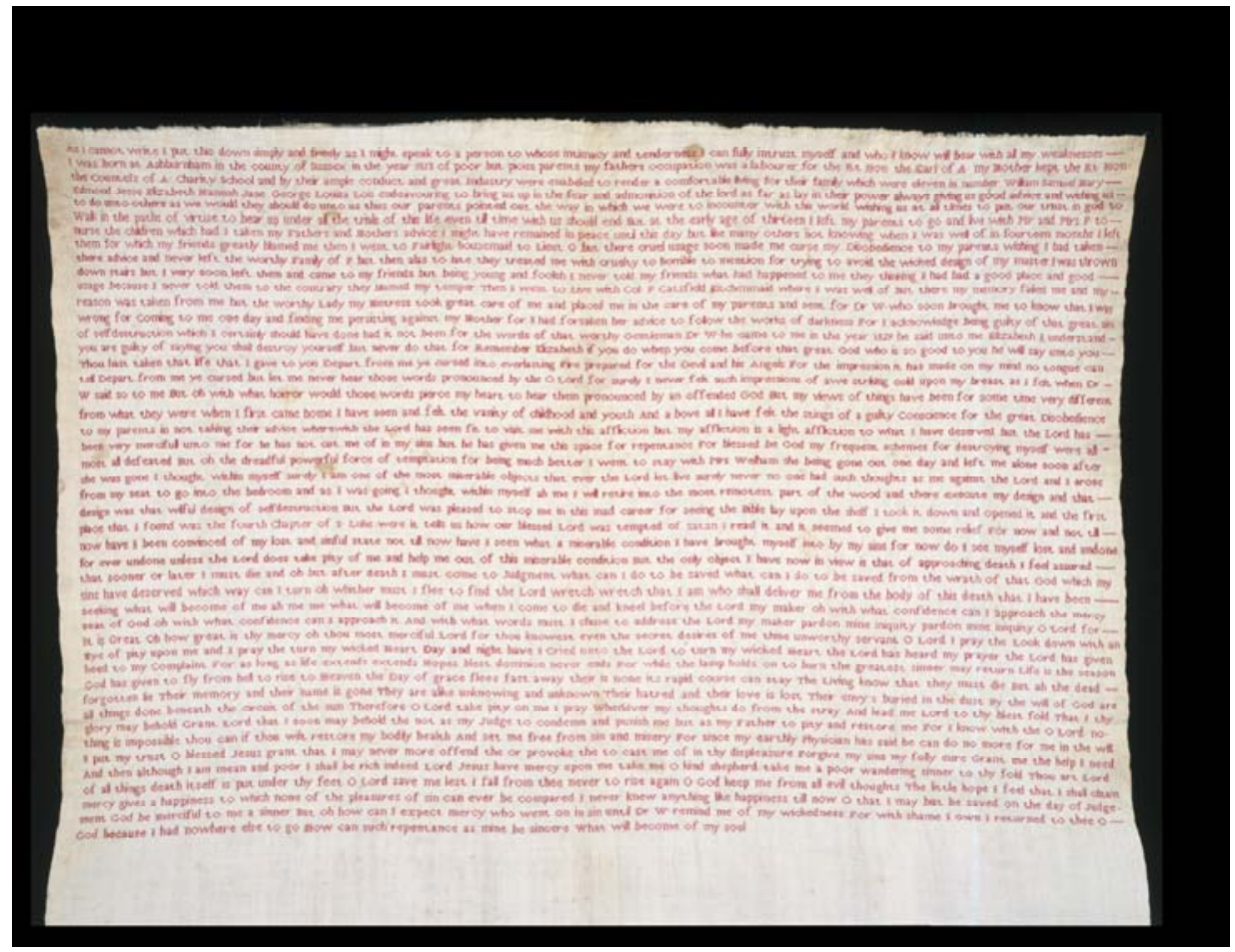

\section{Elizabeth Parkers circa 1830 Sampler}

At first glance, Elizabeth Parker's text/ile appears to be an ordinary plain-stitch sampler, a domestic and domesticating exercise undertaken particularly, though not exclusively, by young women (especially in the late eighteenth and nineteenth centuries) to equip them with skills for positions that would enable Elizabeth Parkers circa 1830 Sampler, (c) V\&A Images/Victoria and Albert Museum, London.

them to avoid potentially horrific circumstances - an escape well captured by Geraldine Clifford's title "Marry, Stitch, Die or Do Worse," a piece in which she examines the limited options for nineteenth-century women. (223-68.)

One of the most common plain-stitch exercises was the marking sampler on which young needleworkers would practice stitching various styles of alphabetic letters and numbers that could be used to mark household and personal items. This work could serve and, in fact, did circulate as a material $C V$. In addition to marking samplers, it was not unusual for nineteenth-century needleworkers to stitch long passages. In fact, one of the distinguishing features of late eighteenth- and nineteenth-century English and American samplers is the dominance of text over motif. A commonplace exercise was the stitching of 
hymns, proverbs, psalms and other sections from the Bible and other moral texts. ${ }^{1}$ However, sampler makers not only copied verses; they also at times recorded important events in their own words. For example, in her sampler (now held at the Museum of London) dated June 28, 1694, Mary Minshull recorded:

THERe WAS AN EARTHQUAKe

ON THE 8 OF SEPTeMBeR 1692

BUT NO HURT THO IT

\section{CAUSED MOST PART OF ENGLAND TO \\ TREMBLe}

Through her silken text, Minshull serves as eyewitness to and historical recorder of this noteworthy event. Her first-hand account contributes additional material evidence to support the newspaper accounts of that day.

Although Elizabeth Parker's sampler appears to fall within the tradition of ordinary plain-stitch samplers, on closer inspection, Parker's sampler is anything but ordinary or plain. In this most uncommon of common text/iles, Parker cross stitched her life story in 46 lines of excruciatingly small letters in red silk on a large piece of tightly-woven linen, measuring some 30 " wide by 34 " long - about the size of a king-sized pillow case. Parker devotes the first 20 of 46 lines to the autobiography of her then brief life of some 17 years, focusing especially on the last four years between the ages of 13 and 17. (See Appendix for full text of Parker's sampler.)

After establishing that she was born in Ashburnham (East Sussex, England) in 1813, that her father was a laborer and her mother was a schoolteacher, she names her ten siblings. Parker then tells us that in 1826, at the age of thirteen under her parents' direction, she took a live-in position as a nursemaid to the children of the worthy Mr. and Mrs. P. Just fourteen months later in 1828, Parker decided to leave that post. She found her own position as a housemaid to "Lieu. G" in Fairlight, a small village just nine miles southeast of Ashburnham. However, she did not last long in this situation. There she was treated "with cruelty to[o] horrible to mention" and while "trying to avoid the wicked design of [her] master [she] was thrown down stairs." (Lines 10-11) Shortly after this horrific experience, Parker took refuge with friends, and after a brief time, left them for yet another live-in position as a kitchenmaid for Col. and Lady P in Catsfield, a small village that lies just over a mile southwest of Battle (site of the famous 1066 Battle of Hastings) and almost three miles southeast of Ashburnham. There Parker's "memory failed [her] and [her] reason was taken from [her]" (Lines 11-12) - classic symptoms of what would today be diagnosed as severe depression. Sir and Lady P sent Parker home and called for "Dr. W."

\footnotetext{
${ }^{1}$ Among the most common sources were hymns by Charles Wesley, Rev. John Newton, and Isaac Watts, and especially popular were verses from Watt's Divine and Moral Songs for Children.
} 
In these lines, Parker narrates what poet Diane Wakoski would call $a$ finger story ${ }^{1}$ of sexual violation and physical abuse at the hands of a supposed protector-her employer Lt. G. These horrific experiences leave unnamed physical, psychological, emotional, and spiritual scars that paralyze her. Her paralysis is compounded by persistent dark thoughts of suicide, thoughts weighed down by very real and potentially severe legal and religious consequences. ${ }^{2}$ The remaining 26 lines inscribe her struggle against, in her words, the "great sin of self destruction" (Line 15) that becomes for her a "dreadful powerful force of temptation" (Line 23) against which she fights almost daily. She prays for God's guidance and mercy but is not convinced that she is worthy of either. After suturing 46 lines, 1,722 words, 6,699 characters (averaging 146 characters per line), she stops abruptly mid-way down the cloth, in mid-line with a powerful plea: "What will become of my soul [?]." (Line 46) Her question is left hanging.

Saturated with her physical, psychological, and spiritual struggles, Parker's piece is a vivid demonstration of an embodied epistemic practice. To justify the claim that a woman's stitching can be interpreted as an epistemic activity, I turn to two key concepts - "situated knowledge" and "embodied knowledge"- both of which have been posited as a way to destabilize the dominant validation of disembodied abstract thinking where the eye serves as the mind's tool of investigation (I see used to mean I understand). ${ }^{3}$ Although eyes are just as embodied as hands, philosophy has managed to elevate the status of eyes making them central to the way in which we conceive of knowing. Patricia Spyer has aptly called this privileged focus on the eye as

${ }^{1}$ This phrase appears in her poem "Medieval Tapestry and Question" in which she writes of a needleworker: "how still she is all day,/her needle flashing in and out of the white cloth,/carrying all the purples and reds, greens,/violets, and yellow in stories, /finger stories." Diane Wakoski. "Medieval Tapestry and Question." In Her Own Image: Women Working in the Arts. Eds. Elaine Hedges and Ingrid Wendt. Old Westbury, NY: Feminist Press, 1980, 38.

2 Olive Anderson. Suicide in Victorian and Edwardian England. Oxford: Clarendon Press, 1987; Victor Bailey. This Rash Act: Suicide across the Life Cycle in the Victorian City. Stanford: Stanford University Press, 1998; and Michael MacDonald, and Terence R. Murphy. Sleepless Souls: Suicide in Early Modern England. Oxford: Clarendon Press, 1990.

3 See Felix Driver. "Bodies in Space: Foucault's Account of Disciplinary Power." Reassessing Foucault: Power, Medicine, and the Body. Ed. Colin Jones and Roy Porter. London: Routledge, 1994, 113-131; Arthur Frank. "Bringing Bodies Back In: A Decade Review." Theory, Culture and Society 7 (1990): 131-62; Donna Haraway. "Situated Knowledges: The Science Question in Feminism and the Privilege of Partial Perspective." Feminist Studies 14 (1988): 575-99; and Carl Knappet., Thinking through Material Culture: An Interdisciplinary Perspective. Philadelphia: University of Pennsylvania Press, 2005. 
"ocularcentrism." (125-9) Here I want to argue for hand work as a way of knowing, what Pamela Smith terms a "material literacy." That is to say that material practices such as needlework are best understood as a form of embodied and hand(y) knowledge making.

This piece of needlework is a powerful rhetorical text. As an artifact, this most extraordinary of ordinary textiles both fits and resists the parameters of canonical genres, namely commonplace notebooks, ${ }^{1}$ autobiographies, ${ }^{2}$ suicide notes, ${ }^{3}$ religious and legal confessions, ${ }^{4}$ and narrative arguments. ${ }^{5}$ The grapholectic marks render it a familiar text/ile. Parker's stitching transformed a material surface into multiple levels of meaning, engaged conflicting purposes and audiences, and wove multiple discourses of a particular historical moment and place. In her struggle and prayer, we witness Parker negotiating in an argument against the nineteenth-century commonplaces of proper behavior circulated by the good Dr. W, by Mrs. Welham with whom she goes to live, and by church and state. She finds herself in a seesaw push/pull of resistance and compliance. She argues with herself as much as with the forces that send her teetering. In a heightened sense, she performs the more inclusive feminist definition of argumentation as "engagement in an issue rather than [only] persuasion to a belief [or social action]." (Ryan and Natalle 69-90)

${ }^{1}$ Susan Miller. Assuming the Positions: Cultural Pedagogy and the Politics of Commonplace Writing. Pittsburgh: University of Pittsburgh Press, 1998; and Ann Moss. Printed Commonplace-Books and the Structuring Of Renaissance Thought. Oxford: Clarendon Press, 1996.

${ }^{2}$ Betty Bergland. "Postmodernism and the Autobiographical Subject: Reconstructing the 'Other'." Autobiography and Postmodernism. Eds. Kathleen M. Ashley, Leigh Gilmore and Gerald Peters. Amherst: The University of Massachusetts Press, 1994, 130-66; Leigh Gilmore. "The Mark of Autobiography: Postmodernism, Autobiography, and Genre." Autobiography and Postmodernism. Eds. Kathleen M. Ashley, Leigh Gilmore and Gerald Peters. Amherst: The University of Massachusetts Press, 1994, 3-18; and Françoise Lionnet. Autobiographical Voices: Race, Gender, Self-Portraiture. Ithaca: Cornell University Press, 1989.

3 MacDonald, and Murphy. Sleepless Souls: Suicide in Early Modern England. Oxford: Clarendon Press, 1990.

4 Leigh Gilmore. "Policing Truth: Confession, Gender, and Autobiographical Authority." Autobiography and Postmodernism. Eds. Kathleen M. Ashley, Leigh Gilmore and Gerald Peters. Amherst: The University of Massachusetts Press, 1994, 5478; and Kathleen M. Swaim. "'Come and Hear' Women's Puritan Evidences." American Women's Autobiographies: Fea(s)ts of Memory. Ed. Margo Culley. Madison: The University of Wisconsin Press, 1993. 32-56.

${ }^{5}$ Glen McClish and Bacon, Jacqueline. "“Telling the Story Her Own Way': The Role of Feminist Standpoint Theory in Rhetorical Studies." Rhetoric Society Quarterly 32 (2002): 27-55. 
Yet, Parker herself begins her text in silken ink with the words "As I cannot write." This enigmatic phrase offers an important starting point for exploring the complex questions: What counts as rhetoric? And who counts in the creation/transformation and circulation/performance of meaning?

\section{“As I Cannot Write": Elizabeth Parker's ca 1830 Sampler}

Although it might be read in a number of ways, the phrase "As I cannot write" may be best understood to signal a self-imposed silence - a metaphorical cutting off of her tongue. It calls to mind the mythical story of Philomela. The most well known version of this myth comes from Book 6 of Ovid's Metamorphosis. In that telling, after Philomela's brother-in-law Tereus the Thracian king rapes her, Philomela vows to tell anyone who will listen to her what Tereus had done: "What punishment you will pay me, late or soon!/Now that I have no shame, I will proclaim it./Given the chance, I will go where people are,/Tell everybody." (146) Locating the power to speak solely in the tongue, Tereus cuts it out, believing he has cut off her power at its source. Yet, as Aristotle in his discussion of various kinds of proofs in the Poetics points out, demonstration and proof can be manifested in many other ways than just by speech. Wounds, for example, themselves are a proof. (3-118. XVI.4.) Aristotle points to Sophicles's use of the myth of Philomela in a now lost play Tereus in which Sophicles calls Philomela's embroidered story "the voice of the shuttle." (XVI.4) Philomela used the voice in her needle as an alternative way to secure discursive power by stitching her account of the violent assault on a robe so her sister Procne and others could learn of it. Procne was thus able to bear witness to the story because of the rhetorical power of Philomela's threadwork.

Similarly, in Shakespeare's Titus Andronicus, Marcus Andronicus alludes to this myth when he first sees his niece Lavinia who has herself been sexually defiled, her tongue cut out, and her hands cut off:

But sure some Tereus hath deflowered thee,

And lest though shouldst detect him, cut thy tongue...

Fair Philomela, she but lost her tongue,

And in a tedious sampler sew'd her mind:

But, lovely niece, that means is cut from thee;

A craftier Tereus, cousin, hast though met,

And he hath cut those pretty fingers off

That could have better sew'd than Philomel[a]. (919-46. II.iv, 930)

Sampler making was not an option for Lavinia since her hands were also cut off; instead, she snatches a copy of Ovid's Metamorphosis from her nephew, young Lucius, and turns to the "tragic tale of Philomela." (IV.i, 935.) At her uncle Marcus's urging to reveal the names of the vile creatures who so brutally 
attacked her, Lavinia places a stick in mouth, and guides it with her stumps to scratch out in the dirt beneath her feet the names of those responsible for the horrors done to her. (IV.i, 934-35)

By analogy, Elizabeth Parker, who will not "speak" and claims she cannot "write," can be understood as metaphorically denied both "tongue" and "hand" but nevertheless succeeds in stitching her mind into a "tedious sampler." Where she departs from both Philomela and Lavinia is in the nature of her argument. Both Philomela and Lavinia seek action; thus, they engage in a more traditional mode of argumentation-persuasion directed at a public audience toward a specific end. By contrast, Parker turns inward. She engages not in contentio but in sermo - a private effort to puzzle through her own personal struggles. For reasons especially particular to her social positioning as a nineteenth century lower-class English women, she does not seek to bring to light or justice the monster who is the source of her pain. ${ }^{1}$

Parker's decision to opt for silence - she refuses to tell friends, family, employers or her doctor what had happened to her — suggests that she was trying to abide by one of the long-standing injunctions to women to be chaste, silent, and obedient. This triadic mandate was meant to close off and thus control all female orifices: chastity kept closed the vagina; silence the mouth; and obedience the eyes downcast. For Parker, the first and last gendered moral laws were, to her mind, already broken. First, having been brutally attacked and sexually assaulted by the vile Lt. G, her chastity had been taken, so she can no longer abide by the first moral mandate. Of the three, this one carried the most severe consequences for women of her day. As Mattingly points out, "because of strict nineteenth-century conventions regarding women's purity, no charges more readily threatened nineteenth-century women than those of immorality and immodesty." (2002a, 68) Second, she blames herself repeatedly for disobeying her parents by leaving the situation they had approved, and by taking a position she herself found. In her words, "above all I have felt the stings of a guilty Conscience for the great Disobedience to my parents in not taking their advice." (Line 20) Downcast eyes were a signifier of obedience, sustaining the hegemonic power structure "that helped keep gendered and class hierarchies in place." (Mattingly , Appropriate[ing] Dress 137) It is perhaps an effort to try to redeem herself in the area of obedience that Parker engages in an arduous task of cross stitching during which her eyes must be kept downcast to focus attention on the work at hand. As Laurie Lieb points out, one "function of needlework, in

\footnotetext{
${ }^{1}$ Of course, the irony here should escape no one. In writing about Parker's story, I am engaging in one of the very kinds of arguments that she herself would not do. On one level, I am making public her story, revealing the "cruelties to[o] horrible to mention" and on another level, I am by the very nature of scholarly argument engaging in contentio.
} 
which the product is less important than the activity itself, is as a means of discipline." (36)

Silence, then, is the only one of the three moral mandates fully available to her. As with the other two commandments, she would have been discursively surrounded by and immersed in this one. Indeed, a common aphorism on samplers of her day was: "Cato doth say to Old and to Young the First step to Virtue is Bridle the tongue." (Ring 71, 250) Yet, Parker abides by a silence of a certain kind; that is, she does not "speak" and she does not "write" in the conventional sense of those terms. But given the devastation she suffered on physical, psychological, emotional and spiritual levels, she cannot remain completely silent.

Yet another way to understand Parker's sampler is to see it as participating in what historian Dominick LaCapra terms "writing trauma." "Writing Trauma," as LaCapra explains, consists of a working through, and acting out, by those who experienced the traumatic event first-hand. Most common among the genres of writing trauma is testimony. Dori Laub explains the function of testimony is integral to the process of working out and through trauma: "What ultimately matters in all processes of witnessing, spasmodic and continuous, conscious and unconscious, is not simply the information, the establishment of facts, but the experience itself of living through testimony, of giving testimony. (85)

The power of testimony cannot be overstated. Laub found in his clinical work with survivors of the Holocaust that they "not only need[ed] to survive so that they could tell their story; they also needed to tell their story in order to survive." (78) In these silken lines, we see Parker quite literally stitching for her life, testifying in red silk in order to survive.

However it is read, Parker's sampler serves as a discursive space in which to cope with debilitating struggles - a space in which to speak what she cannot "speak" and write what she cannot "write" elsewhere. It is a space to grapple with a wounded mind and a wounded body. Understanding this material space as a powerful rhetorical space helps us to rethink what counts as rhetorical praxis and artifact, and who counts in its production, performance and circulation.

\section{Rethinking What Counts as and Who Counts in Rhetorical Praxis and Text}

Of course, turning to a material practice such as needlework requires a defamiliarization of the familiar - a challenge to and deconstruction of the gendered notion that this is "woman's work." And herein lies a paradox. There is, of course, nothing inherent in the practice that makes this work more suitable to women than to men - though some have argued that very point by suggesting women have more delicate fingers and thus can stitch more finely. Prior to the 
seventeenth century, needlework was not associated with one sex, being equally practiced by men and women. Beginning in the seventeenth century, however, it was constructed as "women's work"-a gendered construct that became galvanized by the nineteenth century. ${ }^{1}$ Over this time, the sayings of the father, especially biblical references, became retrospective warrants for constructing sewing as the proper concern of the female and as the appropriate practice of the domestic sphere despite a long, continuous history of men up to this very day engaging in all kinds of needle arts. "Women's work" as an ideological construct became, as historian Merry Wiesner reminds us, "an epithet for the boring, mundane, domestic tasks beneath the dignity of a man." (205) This is especially true of needlework. Yet the sexual politics of stitchery are more complex. As Peter Stallybrass observes: "The gendering of cloth, and of attitudes toward it, has itself been materially inscribed by the social relations through which, outside the capitalist marketplace where the male weaver and male tailor became increasingly the norm, women have been both materially and ideologically associated with the making, repairing, and cleaning of clothes." (35) In other words, within the world of the needle as elsewhere - men were understood to create, women to mend and tidy up. This sexualized perspective - which in real practice was actually much more complicated-was buttressed by "a new rhetoric of exclusion that developed in the eighteenth century and which gradually grew louder as the nineteenth century progressed. The rhetoric praised feminine qualities in male creators ... but claimed females could not - should not-create." (Battersby 3)

The paradox of the gendering of material practices and spaces is that in closing off certain available means and spaces for discourse others are opened. As Glen McClish and Jacqueline Bacon observe, "the connection of language to power means that the mediating role of language is always a defining factor in shaping the discourse of the oppressed. The control that the privileged exert over language means that the marginalized rhetors may have a paradoxical relationship with discourse, but they can negotiate this tension and craft powerful arguments." (32) In other words, "forces that may seem to be in opposition become defining tensions that shape innovative discourse." (33)

In Parker's sampler, we witness her crafting innovative (in the sense of transforming) discourses as she engages in the painful interdynamic negotiations between her experience and the social expectations that define her role in

${ }^{1}$ Judith G. Coffin. "Consumption, Production, and Gender: The Sewing Machine in Nineteenth-Century France." Gender and Class in Modern Europe. Eds. Laura L. Frader and Sonya O. Rose. Ithaca: Cornell University Press, 1996, 114, 111-41. Parker, Subversive Stitch 128; Daniel Roche. The Culture of Clothing: Dress and Fashion in the 'Ancien Regime.' Trans. Jean Birrell. Cambridge: Cambridge University Press, 1994, 252-53; Marla R. Miller. The Needle's Eye; Laurel Thatcher Ulrich, The Age of Homespun. 
society. Her praxis and her piece ought to encourage material culture scholars and rhetoric historians to turn their scholarly gaze toward all sorts of material practices that have taken place in the shadows - hidden, that is, in plain view.

\section{Conclusion: "When This You See, Remember Me"}

As the epigraph that opens this essay suggests, historically, many women (and men, though their work is far less known) have claimed needlework as a powerful rhetorical space. And they continue to do so. Some are like feminist artist Elaine Reichek who creates contemporary needlework samplers both to pay homage to those of previous eras and at the same time to deconstruct the ideology under which these early pieces were stitched. (Cotter 646) Others are like Aunt Jane of Kentucky who take up the needle because as Jane notes, "I reckon everybody wants to leave something behind that'll last after they're dead and gone. It don't look like it's worth while to live unless you can do that." (Hall 78) Nearly a century after Aunt Jane and nearly two centuries after Elizabeth Parker, Molly Finnegan in a 1999 educational broadcast titled "The Fabric of Our Lives: Quilt Making," explained: "I quilt because I don't want my history, my story to die. Quilting gives me a voice when I can't write or speak." (Rief) Pens of steel and silken ink have served needlework-rhetors for untold ages, and as Finnegan's explanation demonstrates, they continue to function as significant semiotic tools. For historians of rhetoric and scholars of material culture, these semiotic fabrics are important for recouping neglected rhetorical practices, artifacts, and traditions in order to weave fuller accounts of the multiple ways meaning is constructed, performed and circulated.

Many sampler makers seemed keenly aware of the value of needlework for leaving a discursive legacy. Indeed, among the most common phrases that appear on many eighteenth- and nineteenth-century samplers is "When this you see, Remember me." In Parker's sampler, she expresses far less optimism. She fingerwrites: "But ah the dead forgotten lie. Their memory and their name is gone. They are alike unknowing and unknown." (Lines 37-38) Too bad she had so little faith in her own discursive work. For in having stitched her story in silken ink, she reminds us of Sappho who in one of her fragments exclaimed: "Someone, I tell you will remember us." (1984) As Cheryl Glenn points out of Sappho's work: "A surviving scrap of Sappho's verse assures us that she knew she would not 'be forgotten'-despite the passage of time and the willful attempts to silence the voices of all women." (Glenn 174-5) Similarly, Elizabeth Parker's surviving scrap assures us (though it didn't assure her) that she too will 
not be forgotten - but only if we look for such material traces and agree that this is a rhetoric and a person whose story is worth telling. ${ }^{1}$

\section{Appendix} Transcription of Text Stitched on Elizabeth Parker's circa 1830 Sampler
(T6-1956)

I have tried to remain faithful to the original, and have thus retained original spelling and include only punctuation marks that were stitched. Line numbers are indicated in brackets.

[1] As I cannot write I put this down simply and freely as I might speak to a person to whose intimacy and tenderness I can full intrust myself and who I know will bear with all my weaknesses [2] I was born at Ashburnham in the county of Sussex in the year 1813 of poor but pious parents my fathers occupation was a labourer for the Rt Hon the Earl of A my Mother kept the Rt Hon [3] the Countess of A Charity School and by their ample conduct and great industry were enabled to render a comfortable living for their family which were eleven in number William Samuel Mary [4] Edmond Jesse Elizabeth Hannah Jane George Louisa Lois endeavouring to bring us up in the fear and admonition of the Lord as far as lay in their power always giving us good advice and wishing us [5] to do unto others as we would they should do unto us thus our parents pointed out the way in which we were to incounter with this world wishing us at all times to put our trust in god to [6] walk in the paths of virtue to bear up under all the trials of this life even till time with us should end But at the early age of thirteen I left my parents to go and live with Mr and Mrs P to [7] nurse the children which had I taken my Fathers and Mothers advice I might have remained in peace until this day but like many others not knowing when I was well of in fourteen months I left [8] them for which my friends greatly blamed me then I went to Fairlight housemaid to Lieu. G but there cruel usage

\footnotetext{
${ }^{1}$ Within the space of this essay, I can offer only a few lines on her life. Elizabeth did find the strength to resist the dreadful force of self-destruction, living another 50 years to the ripe age of 76. Although the records are sparse (she left us no other diary nor was she of a social class that would have the luxury of keeping personal papers or other artifacts), they do indicate that while she never married, she lived a moderately comfortable life as a school teacher in Ashburnham, and that she raised her sister Louisa's youngest daughter Elizabeth French. On the $10^{\text {th }}$ of April 1889, Elizabeth Parker died of a "Haemorrrhage," according to her death certificate. Present at her deathbed in her cottage was her nephew George French, Elizabeth French's older brother. What remains a mystery is how her sampler survived. For more information, see Maureen Daly Goggin. “One Nineteenth-Century English Woman's Story in Silken Ink: Filling in the Missing Strands in Elizabeth Parker's circa 1830 Sampler." Samplers and Antique Needlework Quarterly 29 (Winter 2002): 38-49.
} 
soon made me curse my Disobedience to my parents wishing I had taken [9] there advice and never left the worthy family of $\mathrm{P}$ but then alas to late they treated me with cruelty to horrible to mention for trying to avoid the wicked design of my master I was thrown [10] down stairs but I very soon left them and came to my friends but being young and foolish I never told my friends what had happened to me they thinking I had had a good place and good [11] usage because I never told them to the contrary they blamed my temper Then I went to live with Col. P Catsfield kitchenmaid where I was well off but there my memory failed me and my [12] reason was taken from me but the worthy Lady my mistress took great care of me and placed me in the care of my parents and sent for Dr. W who soon brought me to know that I was [13] wrong for coming to me one day and finding me persisting against my Mother for I had forsaken her advice to follow the works of darkness For I acknowledge being guilty of that great $\sin$ [14] of self destruction which I certainly should have done had it not been for the words of that worthy Gentleman Dr W he came to me in the year 1829 he said unto me Elizabeth I understand [15]you are guilty of saying you shall destroy yourself but never do that for Remember Elizabeth if you do when you come before that great God who is so good to you he will say unto you [16] Thou hast taken that life that I gave you Depart from me ye cursed into everlasting fire prepared for the Devil and his Angels For the impression it has made on my mind no tongue can [17] tell Depart from me ye cursed but let me never hear those words pronounced by the O Lord for surely I never felt such impressions of awe striking cold upon my breast as I felt when Dr [18] W said so to me But oh with what horror would those words pierce my heart to hear them pronounced by an offended God But my views of things have been for some time very different [19] from what they were when I first came home I have seen and felt the vanity of childhood and youth And above all I have felt the stings of a guilty Conscience for the great Disobedience [20] to my parents in not taking their advice wherewith the Lord has seen fit to visit me with this affliction but my affliction is a light affliction to what I have deserved but the Lord has [21] been very merciful unto me for he has not cut me of in my sins but he has given me this space for repentance For blessed be God my frequent schemes for destroying myself were all [22] most all defeated But Oh the dreadful powerful force of temptation for being much better I went to stay with Mrs Welham she being gone out one day and left me alone soon after [23] she was gone I thought within myself surely I am one of the most miserable objects that ever the Lord let live surely never no one had such thoughts as me against the Lord and I arose [24] from my seat to go into the bedroom and as I was going I thought within myself ah me I will retire into the remotest part of the wood and there execute my design and that [25] design was that wilful design of self destruction But the Lord was pleased to stop me in this mad career for seeing the Bible lay upon the shelf I took it down and opened it and the first [26] 
place that I found was the fourth Chapter of St Luke were it tells us how our blessed Lord was tempted of satan I read it and it seemed to give me some relief For now and not till [27] now have I been convinced of my lost and sinful state not till now have I seen what a miserable condition I have brought myself into by my sins for now do I see myself lost and undone [28] for ever undone unless the Lord does take pity of me and help me out of this miserable condition But the only object I have now in view is that of approaching death I feel assured [29] that sooner or later I must die and oh but after death I must come to judgment what can I do to be saved what can I do to be saved from the wrath of that God which my [30] sins have deserved which way can I turn oh whither must I flee to find the Lord wretch wretch that I am who shall deliver me from the body of this death that I have been [31] seeking what will become of me ah me me what will become of me when I come to die and kneel before the Lord my maker oh with what confidence can I approach the mercy [32] seat of God oh with what confidence can I approach it And with what words must I chuse to address the Lord my maker pardon mine iniquity pardon mine iniquity Oh lord for [33] It is Great. Oh how great is thy mercy oh thou most merciful Lord for thou knowest even the secret desires of me thine unworthy servant $\mathrm{O}$ Lord I pray the Look down with an [34] Eye of pity upon me and I pray the turn my wicked Heart Day and night have I Cried unto the Lord to turn my wicked Heart the Lord has heard my prayer the Lord has given [35] heed to my Complaint For as long as life extends extends Hopes blest dominion never ends For while the lamp holds on to burn the greatest sinner may return Life is the season [36] God has given to fly from hell to rise to Heaven the Day of grace flees fast away their is none its rapid course can stay the Living know that they must die But ah the dead [37] forgotten lie Their memory and their name is gone They are alike unknowing and unknown Their hatred and their love is lost Their envy's buried in the dust By the will of God are [38] all things done beneath the circuit of the sun Therefore O Lord take pity on me I pray whenever my thoughts do from the stray And lead me Lord to thy blest fold that I thy [39] glory may behold Grant Lord that I soon may behold the not as my Judge to condemn and punish me but as my Father to pity and restore me For I know with the O Lord no- [40] thing is impossible thou can if thou wilt restore my bodily health And set me free from sin and misery For since my earthly Physician has said he can do no more for me in the will [41] I put my trust $O$ blessed Jesus grant that I may never more offend the or provoke the to cast me of in thy displeasure Forgive my sins my folly cure Grant me the help I need [42] And then although I am mean and poor I shall be rich indeed Lord Jesus have mercy upon me take me O kind shepherd take me a poor wandering sinner to thy fold Thou art Lord [43] of all things death itself is put under thy feet $\mathrm{O}$ Lord save me lest I fall from thee never to rise again $\mathrm{O}$ god keep me from all evil thoughts The little hope I feel that I shall obtain [44] mercy gives a happiness to which none of the pleasures of sin can ever be 
compared I never knew anything like happiness till now $\mathrm{O}$ that I may but be saved on the day of Judge-[45] ment God be merciful to me a sinner but Oh how can I expect mercy who went on in sin until Dr W reminded me of my wickedness For with shame I own I returned to thee O [46] God because I had nowhere else to go How can such repentance as mine be sincere what will become of my soul [...]

\section{Works Cited}

Anderson, Olive. Suicide in Victorian and Edwardian England. Oxford: Clarendon Press, 1987.

Aristotle. Poetics. In Aristotle in Twenty-Three Volumes: The Poetics, Longinus on the Sublime, Demetrius on Style. Translated by W. H. Fyfe, 3-118. 1932. Reprint. Cambridge: Harvard University Press, 1982.

Bailey, Victor. This Rash Act: Suicide across the Life Cycle in the Victorian City. Stanford: Stanford University Press, 1998.

Batchelor, Jennie, and Cora Kaplan. Women and Material Culture, 1660-1830. New York: Palgrave MacMillan, 2007.

Battersby, Christine. Gender and Genius: Towards a Feminist Aesthetics. London: Women's Press, 1989.

Bergland, Betty. "Postmodernism and the Autobiographical Subject: Reconstructing the 'Other". In Autobiography and Postmodernism. Eds. Kathleen M. Ashley, Leigh Gilmore and Gerald Peters, Amherst: The University of Massachusetts Press, 1994. 130-66.

Bizzell, Patricia. "Feminist Methods of Research in the History of Rhetoric: What Difference Do They make?" Rhetoric Society Quarterly 30 (2000): 5-17.

Campbell, Karlyn Kohrs. Man Cannot Speak for Her: A Critical Study of Early Feminist Rhetoric. 2 vols. Westport, CT: Greenwood, 1989.

Clifford, Geraldine. "“Marry, Stitch, Die or Do Worse': Educating Women for Work." In Work, Youth, and Schooling: Historical Perspectives on Vocationalism in American Education. Eds. Harvey Kantor \& David B. Tyack. Stanford: Stanford University Press, 1982. 223-68.

Coffin, Judith G. "Consumption, Production, and Gender: The Sewing Machine in Nineteenth-Century France." In Gender and Class in Modern Europe. Eds. Laura L. Frader, and Sonya O. Rose. Ithaca: Cornell University Press, 1996. 111-41.

Cotter, Holland. "New Samplers that Give Old Pieties the Needle." New York Times. 5 March 1999, Art Review, 646.

Driver, Felix. "Bodies in Space: Foucault's Account of Disciplinary Power." In Reassessing Foucault: Power, Medicine, and the Body. Eds. Colin Jones and Roy Porter. London: Routledge, 1994. 113-131.

Enos, Richard Leo. "The Archaeology of Women in Rhetoric: Rhetorical Sequencing as a Research Method for Historical Scholarship." Rhetoric Society Quarterly 32 (2002): 65-80.

Frank, Arthur. "Bringing Bodies Back In: A Decade Review." Theory, Culture and Society 7 (1990): 131-62. 
Gilmore, Leigh. "The Mark of Autobiography: Postmodernism, Autobiography, and Genre." In Autobiography and Postmodernism. Eds. Kathleen M. Ashley, Leigh Gilmore and Gerald Peters. Amherst: The University of Massachusetts Press, 1994. 3-18.

-_Policing Truth: Confession, Gender, and Autobiographical Authority." In Autobiography and Postmodernism. Eds. Kathleen M. Ashley, Leigh Gilmore and Gerald Peters. Amherst: The University of Massachusetts Press, 1994. 5478.

Glenn, Cheryl. Rhetoric Retold: Regendering the Tradition from Antiquity through the Renaissance. Carbondale: Southern Illinois University Press, 1997.

Goggin, Maureen Daly. "One Nineteenth-Century English Woman's Story in Silken Ink: Filling in the Missing Strands in Elizabeth Parker's circa 1830 Sampler." Samplers and Antique Needlework Quarterly 29 (Winter 2002): 38-49.

Goggin, Peter N. and Maureen Daly Goggin. "Presence in Absence: Discourses and Teaching (In, On and about) Trauma." In National Trauma and the Teaching of Writing. Ed. Shane Borrowman. Albany: State University of New York Press, 2005. 29-51.

Hall, Eliza Calvert. Aunt Jane of Kentucky. Boston: Little, Brown \& Company, 1910.

Haraway, Donna. "Situated Knowledges: The Science Question in Feminism and the Privilege of Partial Perspective." Feminist Studies 14 (1988): 575-99.

Hobbs, June Hadden. "I Sing for I Cannot be Silent”: The Feminization of American Hymnody, 1870-1920. Pittsburgh: University of Pittsburgh Press, 1997.

Jarratt, Susan C. Rereading the Sophists: Classical Rhetoric Refigured. Carbondale: Southern Illinois University Press, 1991.

Knappett, Carl. Thinking through Material Culture: An Interdisciplinary Perspective. Philadelphia: University of Pennsylvania Press, 2005.

LaCapra, Dominick. Writing History, Writing Trauma. Baltimore: Johns Hopkins University Press, 2001.

Laub, Dori. "An Event without a Witness: Truth, Testimony and Survival." In Testimony: Crises of Witnessing in Literature, Psychoanalysis, and History. Eds. Shoshana Felman and Dori Laub. New York: Routledge, 1992. 75-92.

Lionnet, Françoise. Autobiographical Voices: Race, Gender, Self-Portraiture. Ithaca: Cornell University Press, 1989.

Logan, Shirley W. We Are Coming: The Persuasive Discourse of Nineteenth-Century Black Women. Carbondale: Southern Illinois University Press, 1999.

Lunsford, Andrea A., ed. Reclaiming Rhetorica Women in the Rhetorical Tradition. Pittsburgh: University of Pittsburgh Press, 1995.

MacDonald, Michael, and Terence R. Murphy. Sleepless Souls: Suicide in Early Modern England. Oxford: Clarendon Press, 1990.

Mattingly, Carol. Appropriate[ing] Dress: Women's Rhetorical Style in NineteenthCentury America. Carbondale: Southern Illinois University Press, 2002a.

---. “Telling Evidence: Rethinking What Counts in Rhetoric." Rhetoric Society Quarterly 32 (2002b): 99-108.

---. Well-Tempered Women: Nineteenth-Century Temperance Rhetoric. Carbondale: Southern Illinois University Press, 1998. 
McClish, Glen, and Bacon, Jacqueline. “'Telling the Story Her Own Way': The Role of Feminist Standpoint Theory in Rhetorical Studies." Rhetoric Society Quarterly 32 (2002): 27-55.

Miller, Marla R. The Needle's Eye: Women and Work in the Age of Revolution. Amherst: University of Massachusetts Press, 2006.

Miller, Susan. Assuming the Positions: Cultural Pedagogy and the Politics of Commonplace Writing. Pittsburgh: University of Pittsburgh Press. 1998.

Moss, Ann. Printed Commonplace-Books and the Structuring Of Renaissance Thought. Oxford: Clarendon Press, 1996.

Ovid. Metamorphosis. Translated by R. Humphries. Bloomington: Indiana University Press, 1955.

Parker, Rozsika. The Subversive Stitch: Embroidery and the Making of the Feminine. 1984. Reprint. New York: Routledge, 1989.

Peterson, Carla L. Doers of the Word: African-American Women Speakers and Writers in the North (1830-1880). New York: Oxford University Press, 1995.

Ratcliffe, Krista. Anglo-American Feminist Challenges to the Rhetorical Traditions: Virginia Woolf, Mary Daly, Adrienne Rich. Carbondale: Southern Illinois University Press, 1996.

Rief, L., Host. "The Fabric of Our Lives: Quilt Making." In Tales Out of School: Reading and Writing Beyond the Classroom. Produced by S. N. Scully and Directed by T. Van Horn. Star Schools. US Department of Education. Boston: Massachusetts Corporation of Educational Telecommunications, 1999.

Ring, Betty. Let Virtue be a Guide to Thee: Needlework in the Education of Rhode Island Women, 1730-1830. Providence: The Rhode Island Historical Society, 1983.

Roche, Daniel. The Culture of Clothing: Dress and Fashion in the 'Ancien Regime.' Translated by Jean Birrell. Cambridge: Cambridge University Press, 1994.

Royster, Jacqueline Jones. Traces of a Stream: Literacy and Social Change among African-American Women. Pittsburgh: University of Pittsburgh Press, 2000.

Ryan, Kathleen J., and Elizabeth Natalle J. "Fusing Horizons: Hermeneutics and Invitational Rhetoric.” Rhetoric Society Quarterly 31 (2001): 69-90.

Sappho. Sappho: Poems \& Fragments. Translated by Josephine Balmer. Secaucus, NJ: Meadowland, 1984.

Shakespeare, William. Titus Andronicus. In The Complete Works of William Shakespeare. New York: Avenel Books, 1975. 919-46.

Spyer, Patricia. "The Body, Materiality and the Senses." In Handbook of Material Culture. Eds. Christopher Tilley, Webb Keane, Susanne Küchler, Michael Rowlands and Patricia Spyerm. London: Sage, 2006. 125-29.

Stallybrass, Peter. "Worn Worlds: Clothes and Mourning." In Cultural Memory and the Construction of Identity. Eds. Dan Ben-Amos and Liliane Weissberg. Detroit: Wayne State University Press, 1999. 27-44.

Sutherland, Christine Mason. "Feminist Historiography: Research Methods in Rhetoric." Rhetoric Society Quarterly 32 (2002): 109-22.

Sutherland, Christine Mason, and Rebecca Sutcliffe, eds. The Changing Tradition: Women in the History of Rhetoric. Calgary: University of Calgary Press, 1999. 
Swaim, Kathleen M. “Come and Hear' Women's Puritan Evidences.” In American Women's Autobiographies: Fea(s)ts of Memory. Ed. Margo Culley. Madison: The University of Wisconsin Press, 1993. 32-56.

Ulrich, Laurel Thatcher. The Age of Homespun: Objects and Stories in the Creation of an American Myth. New York: Alfred A. Knof, 2001.

Wakoski, Diane. "Medieval Tapestry and Question." In In Her Own Image: Women Working in the Arts. Eds. Elaine Hedges and Ingrid Wendt. Old Westbury, NY: Feminist Press, 1980. 38.

Wertheimer, Molly Meijer, ed. Listening to their Voices: Essays on the Rhetorical Activities of Historical Women. Columbia: University of South Carolina Press, 1997.

Wiesner, Merry E. "Spinsters and Seamstresses: Women in Cloth and Clothing Production." In Rewriting the Renaissance: The Discourses of Sexual Difference in Early Modern Europe. Eds. Margaret W. Ferguson, Maureen Quilligan and Nancy J. Vickers. Chicago: University of Chicago Press, 1986. 191-205. 